\title{
Methylenetetrahydrofolate Reductase C677T \\ Polymorphism and Plasma Homocysteine Levels in Egyptian Patients with Primary Open-angle Glaucoma
}

\author{
Wafaa A Emam¹, Bahaa El Din Hassan ${ }^{2}$ \\ Medical Biochemistry Department ${ }^{1}$ and Ophthalmology Department ${ }^{2}$, \\ Faculty of Medicine Zagazig University
}

\begin{abstract}
Objectives: The association between primary open-angle glaucoma (POAG) and cardiovascular disease has recently stimulated interest in the role of homocysteine in the pathogenesis of glaucoma. In the present study, we aimed to measure plasma homocysteine and its relation to C677T methylenetetrahydrofolate reductase polymorphism in patients with POAG. Subjects and Methods: Fasting venous blood samples from one hundred patients with POAG and 50 age and sex matched healthy control subjects were analyzed for plasma homocysteine by high performance liquid chromatography (HPLC) and genotype for C677T polymorphism by polymerase chain reaction-restriction fragment length polymorphism (PCR-RFLP). Results: There was no statistically significant difference in POAG patients and controls for the age and sex $(P>0.05)$. Mean plasma homocysteine was significantly higher in POAG patients $(12.37 \pm 3.05 \mu \mathrm{mol} / \mathrm{l}$.) compared with controls $(10.40 \pm 1.74 \mu \mathrm{mol} / \mathrm{l}$. $)(P<$ 0.001). C677T polymorphism did not show significant differences between the POAG patients and control subjects (CC: 46\%, CT: 41\%, TT: 13\%) for patients with POAG; CC: $60 \%$, CT: 32:\%, TT: 8\% for controls) (P>0.05). Frequency of $T$ allele was $33.5 \%$ and $24 \%$ for patients with POAG and controls, respectively. Conclusion: In Egyptian patients plasma homocysteine was elevated in POAG patients but no association was found between C677T polymorphism and POAG patients. If homocysteine measurement proves useful for risk stratification, therapies that lower it may aid the management of $P O A G$.
\end{abstract}

Keywords: Primary open-angle glaucoma, Homocysteine, gene C677T polymorphism.

\section{INTRODUCTION}

Primary open-angle glaucoma (POAG) is a slowly progressive multifactorial optic neuropathy characterized by retinal ganglion cell death. It manifests as changes to optic disc, retinal nerve fiber layer, and visual field. ${ }^{\mathbf{1 , 2}}$. It is the second leading cause of irreversible blindness worldwide. $^{3}$

High levels of homocysteine in the aqueous humor and the serum of patients suffering from glaucoma and other ocular diseases have been observed in different studies. ${ }^{4-8}$ Homocysteine can induce neuronal cell death by inducing apoptosis or gliotoxicity, ${ }^{\mathbf{9}, 10}$ vascular injuries, ${ }^{\mathbf{1 1}}$ 
thus representing a hypothetical risk factor for POAG. ${ }^{\mathbf{1 2}}$ Moreover, it causes dysregulation of matrix metalloproteinases and their inhibitors. $^{13}$ Hyperhomocysteinemia has been shown to be involved in the structural remodeling of connective tissues. ${ }^{14,15} \quad$ Homocysteine concentrations are influenced by both environmental and genetic factors, such as mutations in the methylenetetrahydrofolate reductase (MTHFR) gene. ${ }^{16,17}$

MTHFR enzyme catalyzes the reduction of $5^{\prime}, 10^{\prime}$ methylenetetrahydrofolate to $5^{\prime}$ methyltetrahydrofolate, the predominant circulatory form of folate which is the methyl donor for homocysteine remethylation. ${ }^{\mathbf{1 8}}$ Polymorphisms in the gene are associated with a reduced enzyme activity and elevated circulating homocysteine levels. ${ }^{19,20}$ The C677T polymorphism of MTHFR, is characterized by a $\mathrm{C}>\mathrm{T}$ substitution at nucleotide 677 which results in a missense mutation due to the substitution of valine for alanine at position 222 of the MTHFR enzyme. ${ }^{16,21}$ There are conflicting data regarding the association of polymorphisms with glaucoma. Several studies have reported an association of the C677T polymorphism with glaucoma, 2 -25 whereas no association in other studies. $^{4,26-28}$

Since POAG is a disease with a high heritability as shown in population-based studies ${ }^{29,} \mathbf{3 0}$, the present study was conducted to investigate a hypothesized association between C677T polymorphism of MTHFR enzyme and POAG in a sample of Egyptian patients, and their possible association with plasma homocysteine levels hoping that our results will contribute toward a better understanding of the disease's causative agents.

\section{PATIENTS \& METHODS}

\section{Subjects}

This case control study was conducted with 100 Egyptian patients with POAG and 50 control subjects attending the Ophthalmology Clinics of Zagazig University Hospital, Egypt, between April 2010 and July 2011. The study was approved by the ethical committee of Faculty of Medicine, Zagazig University. Informed consent for the experimental use of specimens was obtained from all subjects.

Patients with chronic renal impairment, diabetes mellitus, cancer, or a gastrointestinal malabsorption syndrome were excluded from the study. Subjects who had used anticonvulsant, immunosuppressive therapy, postmenopausal hormone replacement, cholesterol-lowering agents, antidepressants, antimicrobial therapy, and vitamin supplements in the preceding 6 months were also excluded. Patients were excluded if they had any other ocular diseases that would have caused an increase in the intraocular pressure (IOP), a period of steroid administration, trauma, or uveitis, or if they had a history of eye surgery before the diagnosis of glaucoma.

All subjects underwent a complete ophthalmic examination including best-corrected visual acuity, slit-lamp examination, IOP 
measurement using Goldmann applanation tonometer, gonioscopy, and dilated funduscopic examination.

POAG patient was defined by: an IOP before initiation of a pressurelowering therapy of at least $21 \mathrm{~mm}$ $\mathrm{Hg}$, an open anterior chamber angle on a gonioscopic examination, optic disc changes (notching, increased cup/disc ratio), thinning of the neuroretinal rim, glaucomatous visual field defects (inferior or superior arcuate scotoma, nasal step, paracentral scotoma) (assessed by automated static perimetry, Humphrey Visual Field Analyzer 30-2, Humphrey Instruments, San Leandro, $\mathrm{CA}$ ), and with no other contributing pathology.

The control group consisted of 50 unrelated Egyptian patients with other eye problems such as refractive errors or cataract. All controls had an IOP of less than $21 \mathrm{mmHg}$, a cup/disc ratio of less than 0.5 , no history of IOP lowering medications, and no family history of glaucoma and met the same exclusion criteria of POAG patients. Controls were matched to cases by age, gender, and diagnosis of systemic hypertension to make the groups maximally comparable.

\section{Blood sampling}

After overnight fasting ( $>12 \mathrm{~h}$ ), venous blood sample was collected from each participant in ethylene diamine tetra acetic acid (EDTA) treated tubes. Plasma was immediately separated by centrifugation at $1800 \times \mathrm{g}$ for $15 \mathrm{~min}$, coded and stored at $-20{ }^{\circ} \mathrm{C}$ for homocysteine assay, and whole EDTA blood used for DNA extraction.

\section{Total plasma homocysteine}

Processing of samples:

Tubes contain $20 \mathrm{mg}$ of 5Sulfosalicylic acid (SSA) were prepared as follows: a solution of $200 \mathrm{~g} / \mathrm{L}$ SSA in absolute ethanol was divided into $0.1 \mathrm{ml}$ aliquots in $1 \mathrm{ml}$ tubes. After evaporation of the ethanol in an oven (over night at $50^{\circ} \mathrm{C}$ ), the tubes were capped and stored at room temperature. These SSA tubes contain sufficient SSA to deproteinize $0.5 \mathrm{ml}$ of plasma.

Determination of plasma homocysteine:

Chemicals: O-phthaldehyde, 3mercaptopropionic acid (FlukaSwitzerland), 5-SSA, Boric acid and Potassium dihydrogen phosphate (Scientific limited UK), high performance liquid chromatography (HPLC) grade methanol and acetonitrile (Honil, UK), triethylamine (Reidel-dehaen. Germany).

Homocysteine measurement was carried out by programmable HPLC equipment (GBC model dual head pump, Australia), supplied with autosampler LC 1610, online degasser model GT 104 using spherisorb ODS2 column with $3 \mu \mathrm{m}$ particles size $(150 \times 4.6 \mathrm{~mm})$. On the day of analysis $0.5 \mathrm{ml}$ of plasma was transferred to SSA tubes vigorously mixed and centrifuged for $15 \mathrm{~min}$ at $3000 \mathrm{~g}$ the clear supernatants were used for dervitization process. Dervitization was started by the transfer of $20 \mu \mathrm{l}$ of water to an empty reaction vial, followed by the addition of $5 \mu \mathrm{l}$ of sample and $90 \mu \mathrm{l}$ of OPAmercaptopropionic acid reagent. Working solution was prepared on the day of analysis by adding one part of stock to 20 parts of $100 \mathrm{mmol} / \mathrm{L}$ 
borate, $\mathrm{pH}$ 10.0. The sample and reagent were mixed and incubated at room temperature for $3 \mathrm{~min} ; 50 \mu \mathrm{l}$ of neutralizing buffer $(400 \mathrm{mmol} / \mathrm{L}$ potassium dihydrogen phosphate +10 $\mathrm{ml} / \mathrm{L}$ triethylamine) was added, after mixing $3 \mu \mathrm{l}$ of reaction mixture was injected. The mobile phase $\mathrm{A}$ was formed of $1000 \mathrm{ml}$ of phosphate buffer $+1000 \mathrm{ml}$ of water $+4 \mathrm{ml}$ of tetrahydrofurane. Mobile phase B was a mixture of previous buffer, methanol and acetonitrile (50/35/15 by volume). Flow rate was $1.5 \mathrm{ml} / \mathrm{min}$ for $12 \mathrm{~min}$. The composition of the eluent during analysis was shown in Table 1. Perkin Elmer LS 30 luminescence spectrometer was used for detection, the excitation and emission wave length were 230 and $389 \mathrm{~nm}$ respectively. Peak analysis was done using Winchrom 1.2 software. $^{31}$

Hyperhomocysteinemia is defined as homocysteine level $>15 \mu \mathrm{mol} / 1 .{ }^{32}$

\section{DNA extraction}

EDTA peripheral blood samples were obtained from all participants coded and analyzed in a blind manner for genomic DNA extraction using QIA amp DNA Blood Mini Kit supplied by Qiagen GmbH (Hilden, Germany) as described in the user manual. The quality of the genomic DNA was tested using agarose gel electrophoresis.

Genetic analysis using polymerase chain reaction restriction fragment length polymorphism (PCR-RFLP): The C677T polymorphism was genotyped by PCR-RFLP as described by Papoutsakis et $\boldsymbol{a} \boldsymbol{I}^{33}$ using forward primer 5'-TGA AGG AGA AGG TGT CTG CGG GA-3' and reverse primer 5'-AGG ACG GTG CGG TGA GAG TG-3'. The PCR was carried out in final volume of $25 \mu \mathrm{l}$ containing 30 pmol of each primer (Biosource Europe SA, Belgium), $100 \mathrm{ng}$ of genomic DNA template and $12.5 \mu \mathrm{l}$ of $2 \times$ Dream Taq $^{\mathrm{TM}}$ Green PCR Master Mix (MBI Fermentas, Germany).

Table 1 High performance liquid chromatography gradient conditions

\begin{tabular}{|c|c|}
\hline Time, min & $\begin{array}{c}\text { Mobile phase B in } \\
\text { eluent, } \%\end{array}$ \\
\hline 0.0 & 2 \\
\hline 3.5 & 25 \\
\hline 5.2 & 44 \\
\hline 6.9 & 52 \\
\hline 10.0 & 100 \\
\hline 11 & 2 \\
\hline
\end{tabular}

The amplification protocol was as follow: $95{ }^{\circ} \mathrm{C}$ for $10 \mathrm{~min}$; then 35 cycles of $95^{\circ} \mathrm{C}$ for $1 \mathrm{~min}, 65^{\circ} \mathrm{C}$ for 30 $\mathrm{s}$, and $72{ }^{\circ} \mathrm{C}$ for $1 \mathrm{~min}$; then $72^{\circ} \mathrm{C}$ for 7 min using thermal cycler PTC-100 machine (MJ Research, Inc., Watertown, Mass. USA).

PCR products of C677T polymorphism were subjected to digestion with $5 \mathrm{U}$ Hinfl (New England Biolabs, Beverly, MA, USA), for at least $2 \mathrm{~h}$ at $37{ }^{\circ} \mathrm{C}$. The digested products were separated in a $3 \%$ agarose gel electrophoresis system (Maxicell, EC 360 M-E-C apparatus Cooperation. St Petersburg Florida USA) and visualized with ethidium bromide staining under UV transillumination with 100-bp ladder (Pharmacia Biotech, USA).

\section{Statistical Analysis:}

Statistical analysis was conducted using the Statistical Package for the Social Sciences version 13 (SPSS Inc., Chicago IL version 13, USA). Continuous variables were expressed 
as means \pm standard deviation. Categorical variables were expressed as percentages. Differences between continuous variables were analyzed using the Student $t$ test, while those between categorical variables were analyzed using the Chi square $\left(\chi^{2}\right)$ test. Hardy-Weinberg equilibrium analysis was performed to compare observed and expected genotype frequencies using $\chi^{2}$ test. The association between genotypes and glaucoma risk were estimated by the odds ratios (OR) and their 95\% confidence intervals (CI). $P$ value of
$<0.05$ was considered statistically significant.

\section{RESULTS}

Demographic and clinical data characteristics of the study Subjects

Table 2 shows the demographic and clinical characteristics of the POAG and controls. Controls and patients showed no statistically significant differences as regards gender $(P=0.81)$, age $(P=0.26)$, hypertension $(\mathrm{P}=0.96)$, diabetes mellitus $(P=0.64)$, or cardiovascular diseases $(\mathrm{P}=0.41)$.

Table 2: Demographic and clinical characteristics of the primary open-angle glaucoma $(\mathrm{POAG})$ patients $(\mathrm{n}=100)$ and controls $(\mathrm{n}=50)$

\begin{tabular}{|l|l|l|l|}
\hline Variables & POAG patients & Controls & P value \\
\hline Male, No (\%) & $64(64)$ & $33(66)$ & $0.81^{*}$ \\
\hline $\begin{array}{l}\text { Age, yr; range } \\
\text { mean } \pm \text { SD }\end{array}$ & $42-88$ & $42-88$ & $0.26^{* *}$ \\
\hline Hypertension, No (\%) & $65.3 \pm 12.5$ & $62.8 \pm 13.3$ & \\
\hline Diabetes mellitus, No (\%) & $59(59)$ & $27(54)$ & $0.96^{*}$ \\
\hline Cardiovascular diseases, No (\%) & $40(40)$ & $18(36)$ & $0.64^{*}$ \\
\hline
\end{tabular}

$\chi^{2}$ test; ${ }^{* *}$ student $t$ test

Plasma homocysteine levels and glaucoma risk

The mean plasma levels of homocysteine were $10.40 \pm 1.74$ $\mu \mathrm{mol} / \mathrm{l}$. in controls, and $12.37 \pm 3.05$ $\mu \mathrm{mol} / \mathrm{l}$. in the POAG patients with significant increase in POAG patients $(P<0.001)$ and there was significant increase in the frequency of hyperhomocysteinemia in POAG patients than controls $(\mathrm{P}=0.03)$ Table 3.

C677T polymorphism analysis and glaucoma risk

PCR-RFLP analysis of HinfI digestion of MTHFR C677T polymorphism is shown in the figure 1.

The distributions of genotype and allele frequencies for C677T polymorphism in POAG patients and controls are represented in Table 4. The genotype frequencies were conformed to the Hardy-Weinberg equilibrium in controls $(P=0.912)$. In patients with POAG, the frequency of $\mathrm{CC}, \mathrm{CT}$, and TT genotypes were 44, 41 , and $13 \%$ respectively; and in controls, the frequencies were 60,32 , and $8 \%$ respectively. As regard the risk of development of glaucoma, the $\mathrm{CC}$ genotype and $\mathrm{C}$ wild allele were 
taken as references, there was no significant difference in the distribution of CT and TT genotypes or $\mathrm{T}$ allele between POAG and the controls ( $\mathrm{P}$ value was $0.37,0.43$, and 0.11 respectively.

Table 3: Plasma homocysteine levels $(\mu \mathrm{mol} / \mathrm{L})$ in primary open-angle glaucoma (POAG) patients $(n=100)$ and controls $(n=50)$

\begin{tabular}{|l|l|l|l|}
\hline Homocysteine values & Control & POAG & P-value \\
\hline Homocysteine levels (mean \pm SD) $^{\mathrm{a}}$ & $10.40 \pm 1.74$ & $12.37 \pm 3.05$ & $<0.001^{*}$ \\
Hyperhomocysteinemia $^{\mathrm{a}}$, No $(\%)$ & $6(12.0)$ & $29(29.0)$ & $0.03^{* *}$ \\
\hline
\end{tabular}

${ }^{a}$ homocysteine level $>15 \mu \mathrm{mol} / \mathrm{l}$

"student unpaired " $t$ " test.

$\chi^{* *}$ test.

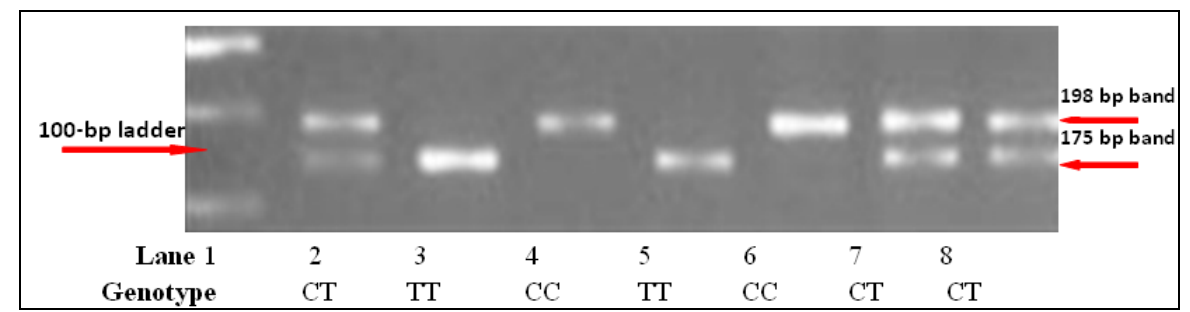

Figure 1 Polymerase chain reaction restriction fragment length analysis of HinfI digestion of C677T polymorphism. Lane 1; $100 \mathrm{bp}$ ladder, lane 2,7,8; three fragments of 198, 175, and $23 \mathrm{bp}$ (not shown) were identified as heterozygous (CT), lane 3,5; two fragments of 175 and $23 \mathrm{bp}$ (not shown) were identified as homozygous mutant (TT) genotype, lane 4,6; a single fragment of $198 \mathrm{bp}$ was identified as homozygous (CC).

C677T gene polymorphism and homocysteine concentrations

Patients with POAG were divided according to the genotype of C677T polymorphism; there was no significant difference in the plasma homocysteine levels among the three genotypes $(P=0.83)$; figure 2 .

\section{DISCUSSION}

The present study has demonstrated significant elevation of plasma homocysteine in Egyptian patients with POAG, which lend support to the hypothesis that there is an association between POAG and elevated plasma homocysteine levels. Homocysteine measurement is exquisitely sensitive to many environmental factors including intercurrent diseases and use of certain medications. ${ }^{34}$. So, all our participants met the chosen exclusion criteria in an attempt to control for the main influences on homocysteine level including vitamin use, renal impairment, diabetes mellitus, and specific medication. 
Table 4: Genotype distributions and allelic frequencies of C677T polymorphism the primary open-angle glaucoma $(\mathrm{POAG})$ patients $(\mathrm{n}=100)$ and controls $(\mathrm{n}=50)$

\begin{tabular}{|l|l|l|l|l|}
\hline $\begin{array}{l}\text { C677T } \\
\text { polymorphism }\end{array}$ & $\begin{array}{l}\text { POAG } \\
\text { patients, } \mathbf{n} \\
\mathbf{( \% )}\end{array}$ & $\begin{array}{l}\text { Controls, n } \\
\mathbf{( \% )}\end{array}$ & $\begin{array}{l}\text { Odds Ratio } \\
\text { (95\% Confidence } \\
\text { interval) }\end{array}$ & $\begin{array}{l}\boldsymbol{P} \text { - } \\
\text { value }^{*}\end{array}$ \\
\hline $\begin{array}{l}\text { Genotypes } \\
\text { CC }\end{array}$ & $46(46)$ & $30(60)$ & 1 (reference) & - \\
CT & $41(41)$ & $16(32)$ & $1.48(0.72-3.02)$ & 0.37 \\
TT & $13(13)$ & $4(8)$ & $1.7(0.53-5.57)$ & 0.43 \\
Alleles & $133(66.5)$ & $76(76)$ & 1 (reference) & - \\
C & $67(33.5)$ & $24(24)$ & $1.60(0.93-2.75)$ & 0.11 \\
T &
\end{tabular}

$\chi^{2}$ test.

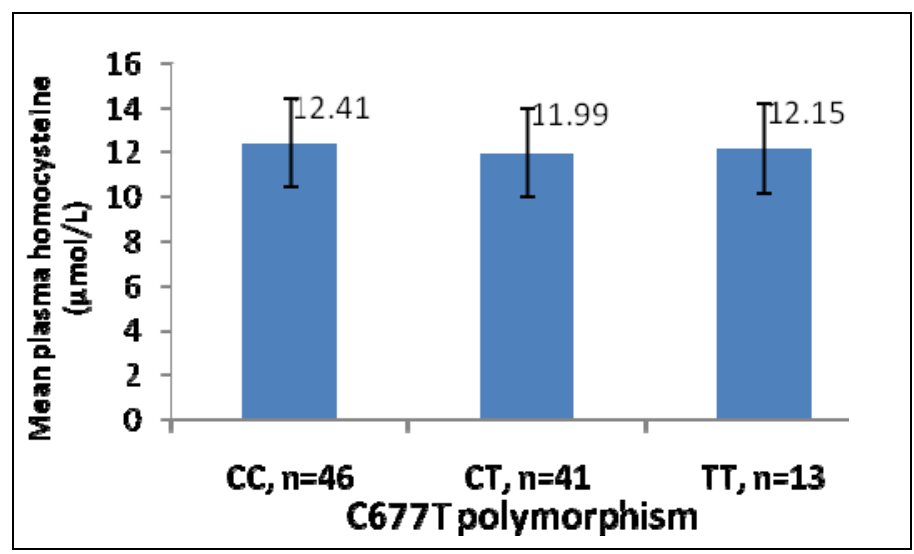

Figure 2 Plasma homocysteine levels in C677T polymorphism carriers in primary open-angle glaucoma patients $(\mathrm{n}=100) . \mathrm{P}=0.83$ (single factor analysis of variance).

The rate of hyperhomocysteinemia varies in different studies. In control subjects the rate of hyperhomocysteinemia in this study was $12 \%$ which is comparable to the result of Leibovitch et al. $(10 \%){ }^{35}$ The reported rates in united state population were $29.2 \%{ }^{36}$ and $36 \%{ }^{37}$; in Australian normal subjects, the rate was very low $(2.4 \%)^{4}$; and in Turkish normal subjects, it was as high as $67.6 \%$, with a mean plasma homocysteine level of $17.43 \mu \mathrm{mol} / 1$ in one study ${ }^{38}$, and $25 \%$ in with a mean plasma homocysteine level of 11.64 $\mu \mathrm{mol} / 1$ in another study. ${ }^{39}$ This difference may be due the method of assessment of homocysteine, the cut of level of hyperhomocysteinemia, and it may also relate to socioeconomic status with good vitamin $\mathrm{B} /$ folate status in some population causing low levels of hyperhomocysteinemia. Nevertheless, it is interesting to note the strong correlation between elevated plasma 
homocysteine and low serum folate in glaucoma patients. ${ }^{40}$

POAG patients were either on topical glaucoma medications and/or had previously undergone laser trabeculoplasty and/or glaucoma filtration surgery. This was in contrast to the control group who had no history of glaucoma treatment. The impacts of topical glaucoma medications on plasma homocysteine levels are unknown.

Reports on plasma homocysteine in POAG ${ }^{6,22,37,39-41}$ have yielded different results. A small number of studies has

investigated the association between homocysteine and POAG with inconsistent results. Bleich et al. ${ }^{5,6}$ have demonstrated that serum homocysteine is elevated in patients with either POAG or pseudoexfoliation glaucoma. Bleich et al. ${ }^{6}$ were the first to demonstrate an association between increased plasma homocysteine levels and POAG, which suggested evidence of its involvement in the pathogenesis of glaucomatous optic neuropathy.

Leibovitch et al. ${ }^{35}$, Vessani et al. $^{36}$ and Altintaş et al. ${ }^{39}$ have independently demonstrated elevation in the levels of total homocysteine in patients with pseudoexfoliative glaucoma. Vessani et al. ${ }^{36}$ have found no association between serum homocysteine and normal tension glaucoma. Also, Wang et al. ${ }^{37}$ failed to find raised homocysteine levels in POAG patients.

It is not clear whether elevated plasma homocysteine contributes to POAG development or progression. Moore et al. ${ }^{10}$ suggested that an elevation in one's homocysteine level may cause changes in the optic nerve head microvasculature and impair optic nerve blood flow via a vasoconstrictive effect, endothelial injury, smooth muscle proliferation, platelet activation, thrombogenesis, and apoptotic cell death in retinal ganglion cells which may cause neuronal cell death, but direct toxic action of homocysteine on retinal ganglion cells are another possible mechanisms.

Some studies, including our study have found no association between the MTHFR C677T gene polymorphism and $P O A G^{4,23,38}$. Micheal et al. ${ }^{42}$ have reported in Pakistanian population that no association of the MTHFR C677T genotype with POAG but a very strong association with primary closed-angle glaucoma which is probably due to the presence of the TT genotype in the disease cohort and its complete absence from the control this population. In contrast to our results, Bleich et al. ${ }^{6}$ and Junemann et al. $^{\mathbf{2 2}}$ have reported increased gene mutation frequencies in POAG patients. These different results may be due to the ethnic difference in the study populations.

The present study revealed that no association between C677T polymorphism and the plasma homocysteine levels, a result that agreed with that of Clement et al. ${ }^{4}$. Similarly, both branch retinal vein occlusion $^{43}$ and non-arteritic ischemic optic neuropathy ${ }^{44}$ are significantly associated with elevated plasma homocysteine levels, but not the frequency of C677T MTHFR polymorphism. The influence of C677T MTHFR polymorphism on homocysteine is complex and 
dependent on the interaction of many factors as homocysteine in MTHFR homozygote that do not smoke is lower than in those that do. ${ }^{45}$ These findings should be interpreted cautiously, bearing in mind the small sample size which may have masked the relationship between the MTHFR polymorphism and POAG.

In conclusion, the current study has demonstrated elevated plasma homocysteine levels in POAG patients. This association was observed in the setting of MTHFR C677T polymorphism frequency not significantly different from controls. The relationship between homocysteine levels, MTHFR polymorphisms and glaucoma warrants further study.

Increased levels of homocysteine in patients with POAG may have important implications for understanding the pathogenesis of glaucomatous optic neuropathy. The results of the study highlight the need for further research to study whether neuroprotection against elevated homocysteine or the lowering of homocysteine will protect patients with glaucoma from glaucomatous optic nerve damage.

\section{Conflict of interest}

We declare that we have no conflict of interest.

\section{REFERENCES}

1. McKinnon SJ, Goldberg LD, Peeples P, Walt JG, Bramley TJ (2008): Current management of glaucoma and the need for complete therapy. Am J Manag Care 14(1 Suppl.):S20-27
2. Mozaffarieh M, Grieshaber MC, Flammer J (2008): Oxygen and blood flow: players in the pathogenesis of glaucoma. Mol Vis, 14:224-233

3. Quigley HA, Broman AT (2006): The number of people with glaucoma worldwide in 2010 and 2020. Br J Ophthalmol., 90(3):262-267

4. Clement CI, Goldberg I, Healey PR, Graham SL (2009): Plasma homocysteine, MTHFR gene mutation, and open-angle glaucoma. J Glaucoma 18(1) :7378

5. Bleich S, Roedl J, Von Ahsen N, Schlötzer-Schrehardt $\mathbf{U}$, Reulbach U, Beck G, Kruse FE, Naumann GO, Kornhuber J, Jünemann AG (2004): Elevated homocysteine levels in aqueous humor of patients with pseudoexfoliation glaucoma. $\mathrm{Am}$ J Ophthalmol., 138(1):162-164

6. Bleich S, Junemann A, Von Ahsen N, Lausen B, Ritter K, Beck G, Naumann GO, Kornhuber J (2002): Homocysteine and risk of openangle glaucoma. $J$ Neural Transm, 109(12) :1499-1504

7. Roedl JB, Bleich S, Reulbach U, Rejdak R, Naumann GO, Kruse FE, SchlötzerSchrehardt U, Kornhuber J, Jünemann AG (2007): Vitamin deficiency and hyperhomocysteinemia in pseudoexfoliation glaucoma. $J$ Neural Transm, 114(5):571-575

8. Sen SK, Pukazhvanthen $P$, Abraham R (2008): Plasma homocysteine, folate and vitamin 
B12 level in senile cataract. IJCB, 23(3):255-257

9. Lipton SA, Kim WK, Choi YB, Kumar S, D'Emilia DM, Rayudu PV, Arnelle DR, Stamler JS(1997): Neurotoxicity associated with dual actions of homocysteine at the N-methyl-Daspartate receptor. Proc Natl Acad Sci USA, 94(11):5923-5928

10. Moore P, El-sherbeny A, Roon P, Schoenlein PV, Ganapathy V, Smith SB (2001): Apoptotic cell death in the mouse retinal ganglion cell layer is induced in vivo by the excitatory amino acid homocysteine. Exp Eye Res, 73(1) :45-57

11. McCully KS (1993): Chemical pathology of homocysteine. I. Atherogenesis. Ann Clin Lab Sci, 23(6):477-493

12. Maler JM, Seifert W, Huther G, Wiltfang J, Ruther E, Kornhuber J, Bleich S (2003): Homocysteine induces cell death of rat astrocytes in vitro. Neurosci Lett, 347(2) : 85-88

13. Bescond A, Augier T, Chareyre C, Garcon D, Hornebeck W, Charpiot $P$ (1999): Influence of homocysteine on matrix metalloproteinase-2: activation and activity. Biochem Biophys Res Commun, 263(2):498-403

14. Mujumdar VS, Tummalapalli CM, Aru GM, Tyagi SC (2002): Mechanism of constrictive vascular remodeling by homocysteine: role of PPAR. Am $J$ Physiol Cell Physiol, 282(5):C1009-1015

15. Wang IJ, Chiang TH, Shih YF, Lu SC, Lin LL, Shieh JW, Wang TH, Samples JR, Hung
PT (2006): The association of single nucleotide polymorphisms in the MMP-9 genes with susceptibility to acute primary angle closure glaucoma in Taiwanese patients. Mol Vis, 12:1223-1332

16. Frosst P, Blom HJ, Milos R, Goyette P, Sheppard CA, Matthews RG, Boers GJH, Heijer DM, Kluijtmans LAJ, Heuvel VDLP, Rozen R (1995): A candidate genetic risk factor for vascular disease: a common mutation methylenetetrahydrofolate reductase. Nat Genet, 10(1):111113

17. Medina M, Urdiales JL, Sánchez MI (2001): Roles of homocysteine in cell metabolism: old and new functions. Eur $J$ Biochem, 268(14):3871-3882

18. Yamada $K$, Chen $Z$, Rozen $R$, Matthews RG (2001): Effects of common polymorphisms on the properties of recombinant human methylenetetrahydrofolate reductase. Proc Natl Acad Sci USA, 98(26):14853-14858

19. Weisberg IS, Jacques PF, Selhub J, Bostom AG, Chen Z, Curtis Ellison R, Eckfeldt JH, Rozen R (2001): The 1298A-->C polymorphism methylenetetrahydrofolate reductase (MTHFR): in vitro expression and association with homocysteine. Atherosclerosis, 156(2):409-415

20. Ueland PM, Hustad S, Schneede J, Refsum H, Vollset SE (2001): Biological and clinical implications of the MTHFR C677T polymorphism. 
Trends Pharmacol Sci, 22(4):195-201

21. Brattstrom L, Wilcken DE, Ohrvik J, Brudin L (1998): Common methylenetetrahydrofolate reductase gene mutation leads to hyperhomocysteinemia but not to vascular disease: the result of a meta-analysis. Circulation 98(23):2520-2526

22. Junemann AG, von Ahsen N, Reulbach U, Roedl J, Bönsch D, Kornhuber J, Kruse FE, Bleich $S$ (2005): C677T variant in the methylenetetrahydrofolate reductase gene is a genetic risk factor for primary open-angle glaucoma. Am $J$ Ophthalmol, 139(4):721-723

23. Mossbock G, Weger M, Faschinger C, Steinbrugger I, Temmel W, Schmut O, Renner W, Hufnagel $C$, Stanger $O$ (2006):

Methylenetetrahydrofolate

reductase (MTHFR) $677 \mathrm{C}>\mathrm{T}$ polymorphism and open angle glaucoma. Mol Vis, 12:356-359

24. Fingert JH, Kwon YH, Moore PA, Johnston RM, Kim KY, Sheffield VC, Alward WL, Stone EM (2006): The C677T variant in the methylenetetrahydrofolate reductase gene is not associated with disease in cohorts of pseudoexfoliation glaucoma and primary open-angle glaucoma patients from Iowa. Ophthalmic Genet, 27(2):39-41

25. Woo SJ, Kim JY, Kim DM, Park SS, Ko HS, Yoo T (2009): Investigation of the association between $677 \mathrm{C}>\mathrm{T}$ and $1298 \mathrm{~A}>\mathrm{C}$ 5,10-methylenetetra- hydrofolate reductase gene polymorphisms and normal-tension glaucoma. Eye (London) 23(1):17-24

26. Zetterberg M, Tasa G, Palmer SM, Juronen E, Toover E, Blennow $\mathbf{K}$, Zetterberg $\mathbf{H}$ (2007):

Methylenetetrahydrofolate reductase genetic polymorphisms in patients with primary openangle glaucoma. Ophthalmic Genet, 28(2):47-50

27. Mabuchi F, Tang S, Kashiwagi $\mathbf{K}$, Yamagata $\mathbf{Z}$, Iijima $\mathbf{H}$, Tsukahara S (2006): Methylenetetrahydrofolate reductase gene polymorphisms c. $677 \mathrm{C} / \mathrm{T}$ and c. $1298 \mathrm{~A} / \mathrm{C}$ are not associated with open angle glaucoma. Mol Vis, 12:735-739

28. Fan BJ, Chen T, Grosskreutz C, Pasquale L, Rhee D, DelBono E, Haines JL, Wiggs JL (2008): Lack of association of polymorphisms in homocysteine metabolism genes with pseudoexfoliation syndrome and glaucoma. Mol Vis, 14:24842491

29. Tielsch JM, Katz J, Sommer A, Quigley HA, Javitt JC (1994): Family history and risk of primary open angle glaucoma. The Baltimore Eye Survey. Arch Ophthalmol, 112(1):69-73

30. Wolfs RC, Klaver CC, Ramrattan RS, van Duijn CM, Hofman A, de Jong PT (1998): Genetic risk of primary openangle glaucoma. Populationbased familial aggregation study. Arch Ophthalmol., 116(12):16401645 
31. Terrlink T, Van Leeuwen PA, Houdijk A (1994): Plasma amino acids determined by liquid chromatography within 17 minutes. Clin Chem, 40 (2):245249

32. Borson-Chazot F, Harthe $C$, Teboul F, Labrousse F, Gaume C, Guadagnino L, Claustrat B, Berthezene F, Moulin P (1999): Occurrence of hyperhomocysteinemia 1 year after gastroplasty for severe obesity. J Clin Endocrinol Metab, 84(2):541-545

33. Papoutsakis $\mathbf{C}$, Yiannakouris $\mathbf{N}$, Manios Y, Papaconstantinou E, Magkos F, Schulpis KH, Zampelas A, Matalas AL (2005): Plasma homocysteine concentrations in Greek children are influenced by an interaction between the methylenetetrahydrofolate reductase C677T genotype and folate status. J Nutr, 135(3):383388

34. Refsum H, Smith AD, Ueland PM, Nexo E, Clarke R, Mc Partlin J, Johanston C, Engbaek F, SchneedeJ, Mc Partlin C, Scott LM (2004): Facts and recommendations about total homocysteine determinations: an expert opinion. Clin Chem, 50(1):3-32

35. Leibovitch I, Kurtz S, Shemesh G, et al. (2003): Hyperhomocysteinemia in pseudoexfoliation glaucoma. $J$ Glaucoma, 12(1):36-39

36. Vessani RM, Ritch R, Liebmann JM, Jofe M. (2003): Plasma homocysteine is elevated in patients with exfoliation syndrome. Am J Ophthalmol, 136(1):41-46

37. Wang G, Medeiros FA, Barshop BA, Weinreb RN. (2004): Total plasma homocysteine and primary open angle glaucoma. $\mathrm{Am} \mathrm{J}$ Ophthalmol, 137(3) :401-406

38. Turaçli ME, Tekeli O, Özdemir F, Akar N (2005): Methylenetetrahydrofolate reductase $677 \quad \mathrm{C}-\mathrm{T}$ and homocysteine levels in Turkish patients with pseudoexfoliation. Clin Exp Ophthalmol, 33(5):505508

39. Altintaş $\mathrm{O}$, Maral $\mathrm{H}$, Yuksel $\mathbf{N}$, Karabaş VL, Dillioğlugil MO, Cağlar Y (2005): Homocysteine and nitric oxide levels in plasma of patients with pseudoexfoliation syndrome, pseudoexfoliation glaucoma and primary open angle glaucoma. Graefes Arch Clin Exp Ophthalmol, 243(7): 677-683

40. Cumurcu T, Sahin S, Aydin E. (2006): Serum homocysteine, vitamin B12 and folic acid levels in different types of glaucoma. BMC Ophthalmol, 6:6

41. Roedl JB, Bleich S, Reulbach U, von Ahsen N, SchlötzerSchrehardt U, Rejdak R, Naumann GOH, Kruse, J. Kornhuber FE, Jünemann AGM (2007): Homocysteine levels in aqueous humor and plasma of patients with primary open angle glaucoma. J Neural Transm, 114(4):445-450

42. Micheal S, Qamar R, Akhtar F Khan MI, Khan WA, Ahmed A (2009): MTHFR gene C677T and A1298C polymorphisms and homocysteine levels in primary 
open angle and primary closed angle glaucoma. Mol Vis. $15: 2268-2278$

43. Weger $M$, Stanger $O$, Deutschmann $H$, Temmel $W$, Renner W, Schmut O, Quehenberger F, Semmelrock J, Haas A (2002): Hyperhomocyst(e)inemia, but not methylenetetrahydrofolate reductase $\mathrm{C} 677 \mathrm{~T}$ mutation, as a risk factor in branch retinal vein occlusion. Ophthalmology, 109(6):1105-1109

44. Weger $M$, Stanger $O$, Deutschmann H, Simona $M$, Rennerc W, Schmuta O, Semmelrockd J, Haas A (2001):
Hyperhomocyst(e)inemia, but not MTHFR C677T mutation, as a risk factor for non-arteritic ischemic optic neuropathy. $\mathrm{Br} J$ Ophthalmol, 85(7):803-806

45. Brown KS, Kluijtmans LA, Young IS, Murray L, McMaster D, Woodside JV, Yarnell JW, Boreham CA, McNulty H, Strain JJ, McPartlin J, Scott JM, Mitchell LE, Whitehead AS (2004): The 5,10- methylenetetrahydrofolate reductase $\mathrm{C} 677 \mathrm{~T}$ polymorphism interacts with smoking to increase homocysteine. 174(2):315-322

\section{التعدد الشكلي C677T لجين مختزل رابع هيدرو مثيلين الفولات وهوموسيستايين البلازما في المرضى المصريين المصابين بالجلوكوما مالينا مفتوحة الزاوية المرية}

تهدف هذه الدراسة استقصاء مدى علاقة التعدد الشكلي C677T لجين مختزل رابع

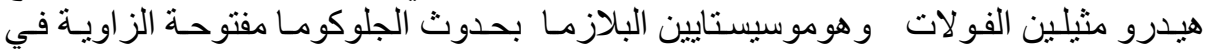
المرضى المصريين.

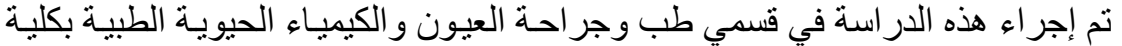

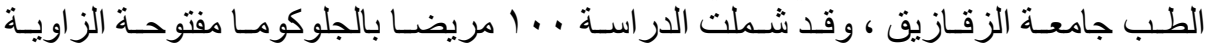

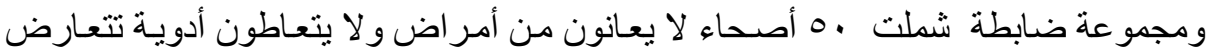

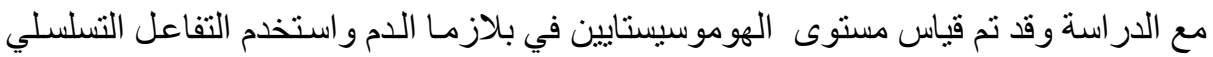

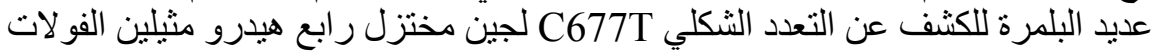

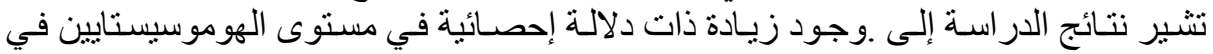

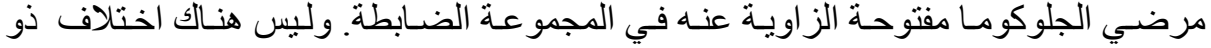

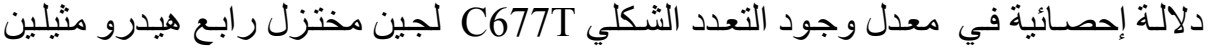
الفولات في مرضى الجلوكوما مفتوحة الزاوية عنه في المجمو عة الضنابطة . 